\title{
The Grey Zone of Subjectivity. Phenomenology of the feminine body in Emmanuel Lévinas's thought ${ }^{20}$
}

\author{
Marzena Adamiak \\ Institute of Philosophy and Sociology \\ Polish Academy of Sciences \\ madamiak[]ifispan.waw.pl \\ Received January 2015; accepted June 2015; published Summer 2015.
}

\begin{abstract}
The concept of a "woman figure" by Emmanuel Lévinas, is an example, in which the notions of "masculinity" and "femininity" serve to determine the character of a certain proposition of a Subject. Lévinas introduced sexual characteristics into the neutral subject, yet he is incon-sistent in his treatment of the idea of a Woman and, moreover, he assigned subjectivity to a single gender: the masculine. Nonetheless, the criticism of Lévinas's model of femininity from a feminist viewpoint is neither simple nor clear. Lévinas continually evades such criticism. He re-established the body and sensuality as key aspects of meeting with the Other. And also, he criticizes the Western ontological tradition as a theoretical source of violence against the Other, since - as he claims - on a high level of abstraction it appears that thematisation itself is a violence. At the same time, Lévinas proposes ontology of a "woman". In relation to this, one needs to ask the question: why does Lévinas, whilst stating the need to be freed from ontology, at the same time create an ontological woman? And additionally, what are the philo-sophical and ethical consequences of the phenomenology of femininity that are presented by Lévinas?
\end{abstract}

Keywords: ontology; subject; femininity; woman; other.

\footnotetext{
${ }^{26}$ This article has been prepared on the basis of my book published in Polish (Adamiak 2007) entitled O kobiecie, która nawiedza myśl. Kobieta jako figura inności w koncepcji podmiotu Emmanuela Lévinasa (Of Woman Who Comes to Mind. Woman as a Figure of Otherness in The Concept of Subject of Emmanuel Lévinas). It presents the analysis of the categories of the subjectivity, the Other and femininity and enumerates the weak points of Levinas's ethical project, to be found directly in his texts. Many polemics and interpretations of this issue have been inevitably skipped here. In my book there are separate chapters dealing with criticism of Levinas's thought done by Simone de Beauvoir, Luce Irigaray and Sabine Gürtler and references to the texts of Sylviane Agacinsky, Catherine Chalier and authors working on feminist phenomenology.
} 
But, sisters, are we cups and bottles, vessels and boxes? Are we orb-weaving spiders crouched in the web of our wombs, or blind spiders living in the underground of our furtiviti? Are we so interior and occult? Hecate, no! No more or less than men.

(Natalie Angier)

\section{The elusive beginnings}

The beginnings of sexuality, just as many other beginnings, are elusive. It is difficult to determine the moment when we become creatures endowed with particular sex. We might even wonder whether such a moment occurs at all. Is there the actual time in human life when we embody Derrida's aporia of Neither/Nor in order to later be deprived of this convenient paradox for the benefit of Kirkegaard's Either/Or? Despite this, the mythical time between gametes being combined into a zygote and assigned with the sexual signum is what has developed to become the philosophers' Mecca. When philosophy searches for the source, traces the beginnings and attempts to describe the encountered phenomena, does the philosopher's mind become awakened or rather, does it remain dormant dreaming of a neutral subject where everything is freed from differences, and particularly, from this most troublesome one? Michel Foucault claimed that the anthropological dream had replaced the dream of God, thus suggesting that once the Man collapses, the era of Discourse will unfold. One might wonder whether this entails a certain significant transformation. The God, the Man, the Discourse represented as The Same Ones or as The Others, were always sexually neutral and kept guard over the source. Meanwhile - as Luce Irigaray noted - there is no such thing as a human, there are men and women. Nonetheless, does the statement of this "empirically obvious" fact disturb our cultural dream of Androgyne - the ideal being raised above sexuality, above the differences of male and female bodies, feminine and masculine thoughts and feelings? The question about a "woman", on the other hand, results from the discourse on a neutral subject. It puts this discourse into question. And, what is more, it anticipates the question concerned with a "man".

Emmanuel Lévinas is one of the few philosophers who decided to explore the topic related to the sex. In his writings we encounter the category of femininity. At first it is incidental and appears in the context of his reflections on sexuality, death and otherness, in order to be later developed into a real ontology. Femininity is depicted as a figure of otherness, and it is the concept of the Other that Lévinas bases his ethical thought on. However, a woman proves to be a distinctive type of otherness. Not the "correct" otherness that Lévinas is in fact interested in. The "correct" otherness is expressed with the use of such figures as the Master, the Father, the Son - i.e. masculine figures. Thus, a man 
is able to find numerous figures that may serve his self-identification. These are not sexually predetermined figures, although, obviously one may note here the presence of crypto-determination. The figure of a woman is singular specific, attached to her erotic function, or, to be more general - her carnality.

The majority of metaphors used by Lévinas, establishing the phenomenology of meeting of a subject, which he calls the Same, with the Other, are metaphors based on the experiences of the body. This is initiated with a hypostasis, which is located in the body where it begins its subjective existence, through the category of enjoyment conditioning the subject's development, to the enigmatic concept of the Face that unveils the possibility of an epiphany. The body constitutes an important condition for separation, it designates the limits of a solitary and autonomous monad. The embodiment releases hypostasis from the amorphous il $y a$, brings it to life. The body is not merely an object like other material objects surrounding the subject - it is an own thing, allowing meaningful experience of oneself.

The encounter between the male Same and the female Other in an erotic situation is also a meeting of two bodies, yet this experience is of a highly specific nature. Femininity cannot be depicted through a description, neither that typical of a subject which Levinas calls the Same, nor the one aimed to characterise the Other. It proves to be an otherness which is not complete nor does it have the power to question the egoism of the subject and open it to the dimension of Transcendence.

\section{Without the face - running away from the light}

What characterises the phenomenology of a woman presented by Lévinas? Femininity hides in the shade of understatements, "flies before light" (1987b: 87). What is observed is the principle of irreducible ambiguity. A female body is delicate, weak and fragile, it requires protection; however, "this extreme fragility lies also at the limit of an existence "without ceremonies», "without circumlocutions», a "non-signifying» and raw density, an exorbitant ultramateriality" (1979: 256). According to Lévinas, the concept of ultramateriality" is to reflect the peculiar paroxysm of materiality. A woman unceremoniously attacks with her naked body, despite the fact that it is fragile and helpless. Thus, the female paroxysm consists in a certain type of hysteria, a neurotic act consisting in a violent unveiling of her presence. The presence without substance, unshaped, "not nothingness - but what is not yet" (1979: 256).

In Lévinas's view, the situation of "the not-yet-being" is not a dynamic one with regard to the possibility of its transgression. This incompleteness constitutes an ontological status of feminine "being". The "being" is put into quotation marks as in fact it is a "presence without essence". It should also be highlighted that this is not a situation of the movement "beyond essence", desired 
in Lévinas's thought, i.e. transgressing one's existence towards the transcendence. The "yet" indicates a certain effort or direction of being. It struggles to become an existence; however, it is incapable of it due to its "essence" that is exhausted not so much in its secretiveness as rather through the permanent incapacity. It is as if a frozen hypostasis. Something emerged from an impersonal and amorphous il y a, yet it does not become a person nor take a concrete shape. Even though Lévinas suggests that "the not-yet-being" does not mean not to be something other; this is merely an assumption that he makes in the attempt to formulate a paradoxical description of femininity - expressing it as a certain "lack", nonetheless evoking positive connotations. This is as if he wanted to forge the said deficiency into feminine positivity - show his appreciation for the lack - and thus move far beyond the Freudian perspective, yet recklessly confirming it all the same.

Living by pleasures offered by the world is referred to as enjoyment and it becomes an important process in shaping of the identity. However, this does not concern the pleasure taken in erotic love due to this sacrilegious impulse to take delight in another being, another person. Erotic nakedness is a profanation, which at the same time emphasises and disproves the sacrum of human existence. And yet, sexuality does bring pleasure. Thus, the being of the Other that participates in this relation needs to be construed in such a way as to allow experiencing pleasure in spite of all; to reveal and disguise, to oscillate on the verge between being and not-being, between the subject and the object, permanently reside in the grey zone.

That is why the female Other is both fragile and weak like the Other that requires the care of the Same and which calls upon it, but at the same time she is shamelessly ultramaterial, which brings her closer to the animal world. The dependence of female "being" on its glimmering, ambiguous carnality appears to be the most significant aspect in its determination. "The simultaneity of the equivocation of this fragility and this weight of non-signifyingness [nonsignificance], heavier than the weight of the formless real, we shall term femininity" - as Lévinas writes (1979: 257).

The possibility of enjoying femininity by the Same is moreover made attainable by the fact that the Woman participating in an erotic relationship - the Beloved - is deprived of the Face: the weird non-phenomenon indicating both the otherness and the Infinity. "The face signifies by itself" - as Lévinas states (1979: 261). It does not gain meaning in relation to something else. It itself endows reality with sense thanks to the light it casts. It allows the thoughts, actions and objects to assume their meaning. And this is what causes the relationship with the Other to be asymmetrical. The Same is not capable of becoming freed from the absurdity of il $y a$. As long as it does not experience the epiphany of the Face, il y a will remain in the background of its existence, even if as a subject it has the power over the elements. Moreover, through this 
experience, the I itself finally is able to gain meaning. One might say that identity is established in order to experience the encounter with the Infinity.

"In the face the existent par excellence presents itself. And the whole body a hand or a curve of the shoulder - can express as the face" (1979: 262). Thus, the Face is a kind of a function assumed by a fragment of being - the body, in order to display the presence of the Other, it is a trace of the Other that the Same encounters. The said encounter is not a simple result of a sensual experience - co-created by the subject through its perception or felt in the enjoyment. The impression to which the subject is exposed to at the moment of epiphany is not his own, it is what is provided from the outside.

In Lévinas's phenomenology, femininity is a figure of otherness, hence it may seem that it should be manifested through the Face. However, the chapter entitled Phenomenology of Eros, in which we find the description of the Beloved, is a part of the section entitled - Beyond the Face. Why is it so?

The difference between experiencing the female Other in an erotic relationship and encountering the Face of the Other and fulfilling of the ethical relationship lies in the fact that the real revelation does not take the sensual path. According to Lévinas - "Revelation is speech" (1979: 193). The Face, as a transcendental being, is revealed in speaking to another person, as - in Lévinas's opinion - "the absolute difference, inconceivable in terms of formal logic, is established only by language". Language, on the other hand, may be defined as "the very power to break the continuity of being or of history" (1979: 195). Lévinas introduces a terminological differentiation within his own concept of language. Language (le dire) is a living expression of the Face, the premeaning that is expressed also through silence. It is the weight of silence - as Lévinas remarks - that often causes the Other to slip away from thematisation. Language appears prior to signs that it combines into language-systems and semantic nuances, it is the pre-speech of the tongue and - as Lévinas puts it - it is most of all "the proximity of one to the other, the commitment of an approach, the one for the other, the very signifyingness of signification" (Decloux-Levinas 1991: 5).

The situation is different in the case of "the said" (le dit), i.e. the language that has already been realised and displayed through a system of recognisable and objectivised signs. Le dit belongs to the world of thematisation, the Totality and power of the subject. Whereas le dire is calling upon the Face, an archaic speech, the living source of the language; le dit is in a sense dead, fossilised in a fixed form. By addressing me, the Other calls me from beyond the defensive rhetoric of predictable series of words that have been uttered thousands of times before. The Other questions the sense that I impose on him. This is the moment when the transcendence is fulfilled. "The solipsist dialectic of consciousness always suspicious of being in captivity in the same breaks off" 
(1979: 195). This break constitutes the opening to a different level of existence, the dimension that is "beyond being".

The Face is the countenance with which I am "faced", it is the opposition in its proper sense involving moral questioning of the subject's power by the Other. This move comes from the Other, hence the doubt is authentic, it originates beyond the subject, beyond its "a priori depths" (1979: 196). "The Face with its morality is external" (1979: 265). The woman as the Other is devoid of the Face, and this is something that stems from her "nature". The Face means - as Lévinas puts it, whereas the Beloved appears before the Same in her equivocation.

Equivocation constitutes the epiphany of the feminine - at the same time interlocutor, collaborator and master superiorly intelligent, so often dominating men in the masculine civilization it has entered, and woman having to be treated as a woman, in accordance with rules imprescriptible by civil society (1979: 264).

One may not neglect to note that what is meant here is the "empirical woman" and not merely the phenomenon of femininity. When a woman functions as a subject, when she builds her identity on the power of freedom of egoism, she enters the masculine civilisation. The roles that she assumes while functioning in a non-erotic world are of masculine gender: the interlocutor, collaborator, a remarkably intelligent teacher ${ }^{27}$ and, what is barely a consolation, often way more competent than men; however, at the same time, this creature is a woman who as such is required to be treated in a special manner, accordingly to the "rules imprescriptible by civil society". The aspect of subjectivity was inscribed into the feminine equivocation and thus a "female human being" does not become the same subject as a "male human being". This combination of a male social role and femininity perceived through the prism of eroticism, i.e. as Lévinas puts it - the equivocation, never relieves the woman of her sexuality. Even when she becomes a "collaborator" or "master", she still remains a woman. A woman that is to be treated in a defined way. The said treatment may be gallant or vulgar, depending on the intention; nonetheless, it is invariably assigned to her sexual function. On the other hand, the perception of a man fulfilling a public function is not linked to his sex.

Thus, although the masculine Other calls upon the masculine Same through a revealed meaning of the face, which is realised as an ethical event par excellence, femininity tempts with a promise of a certain mysterious meaning, simulation of a face, simulation of a subject - the equivocation.

The feminine presents a face that goes beyond the face. The face of the beloved does not express the secret that Eros profanes; it ceases to express, or, if one pre-

\footnotetext{
${ }^{27}$ Also in the original: interlocuteur, collaborateur, maitre supérieurement intelligent; although the feminine forms of those words also exist in French: interlocutrice, collaboratrice, maittresse.
} 
fers, it expresses only this refusal to express, this end of discourse and of decency, this abrupt interruption of the order of presences (1979: 260).

The "face" of the Beloved must not express the secret defiled by Eros, as femininity itself embodies Eros profaning the secret. Similarly, as the woman's body suggested identity and by revealing its lack threw the Same off balance, the woman's face implies Infinity in order to suddenly refuse expression and be stopped in the darkness that leads nowhere. The face that slips away from the light, on the other hand, leads towards a greater light, which is not the light of human insight and intuition.

Why doesn't the female body eventually become the possibility of the face? Isn't a woman's back bent or aren't her eyes begging for help? Lévinas would have answered - certainly, yet in this situation she does not act as a woman. Femininity as sexuality covers the face and the hunched back in order to make room for the pleasure.

The carnal, the tender par excellence correlative of the caress, the beloved, is to be identified neither with the body-thing of the physiologist, nor with the lived body [corps propre] of the "I can", nor with the body-expression, attendance at its own manifestation, or face (1979: 258).

The body of the Beloved does not fit all of the thus far defined depictions, it is not an object, a home of the subject, an expression of the Other. "The Beloved, at once graspable but intact in her nudity, beyond object and face and thus beyond the existent, abides in virginity" (1979: 258).

A question arises: how is it possible for a subject, by nature committed to eroticism, to persist in virginity? How is it achievable by the being that so willingly exhibits its physicality and loses itself in pleasure? It is only possible to last in virginity and at the same time indulge in pleasure for a being that does it by not having another choice, i.e. innocently - without guilt, but also - without assuming responsibility. The woman does not assist the way that she appears. Hence, the phenomenology of the Beloved makes use of metaphors comparing the woman to an animal or a child.

The beloved is opposed to me not as a will struggling with my own or subject to my own, but on the contrary as an irresponsible animality which does not speak true words. The beloved, returned to the stage of infancy without responsibility this coquettish head, this youth, this pure life "a bit silly" - has quit her status as a person. The face fades, and in its impersonal and inexpressive neutrality is prolonged, in ambiguity, into animality. The relations with the Other are enacted in play; one plays with the Other as with a young animal (1979: 263).

Still, there is a certain difference in a child's innocence and a woman's persistence in virginity, as a child is the Other in the proper sense. A child is terrified of $i l y a$ that it has just emerged and seeks the protection of adults. However, a child is a germ of subjectivity, "the not-yet-being" that is to develop, to learn to work and indulge, to control the elements. Whereas the essence of 
femininity dwells in "eternal virginity", the perseverance in "the not-yetbeing". She hides in the sphere of the night, similar to the night of il y a. That is why the innocence and the slightly grave substantialism of a woman's nature - which, by the way, conditions her existence in the biological world - is more of an animalistic rather than a child-like character. A child is not equivocal or ultramaterial. It will become a subject one day. Of course, as long as it is a son.

Lévinas seems not to see the great suffering resulting from such a conditioning. The suffering caused by the entrapment in the sex and sexuality. This specific suffering which is not manifested by calling upon the face that says "Do not kill" but a hysterical exposure of the body crying silently "Kill me". For this reason the eros and tanatos are so closely related with each other. By being deprived of the face a woman attacks with all her body and this is the reason for the said act of exhibitionism and ultramateriality. The debauched exposure of the body may be interpreted as a desperate attempt to exceed the weakness and "subjectlessness", an effort to abandon the hated role of a female Other, as Simon de Beauvoir would put it. Similarly to Luce Irigaray, who interprets female hysteria as a sort of defence against the expectations of patriarchal culture.

The mumbling and yelling by a hysteric is neither the expression of the subject nor a language through which the face is manifested. A woman's silence is not the meaningful silence of the face but merely a meaningless "not speaking". A woman is the Other, who not so much as remains silent as does not speak, whilst language constitutes the fundamental metaphysical relation.

The principle "you shall not commit murder", the very signifyingness of the face, seems contrary to the mystery which Eros profanes, and which is announced in the feminnity of the tender. In the face of the Other expresses his eminence, the dimension of height and divinity from which he descends. In his gentleness dawns his strength and his right. The frailty of femininity invites pity for what, in a sense, is not yet, disrespect for what exhibits itself in immodesty and is not discovered despite the exhibition, that is, is profaned (1979: 262).

However, Lévinas also notes that "disrespect presupposes the face". As a lack of respect is in a sense an act of refusal to show respect. Objects and elements do not aspire to this category at all. Thus, we may say that in an erotic relationship a woman "loses her face", which means that she loses her face by becoming a woman. The decency characteristic of the face succumbs to obscenity and lasciviousness, hence "the feminine is the face in which trouble surrounds and already invades clarity" (1979: 262). However, according to Lévinas this is what the woman's charm is all about.

In this inversion of the face in femininity, in this disfigurement that refers to the face, non-signifyingness abides in the signifyingness of the face. This presence of non-signifyingness in the signifyingness of the face, or this reference of the non- 
signifyingness to signifyingness (...) is the primordial event of feminine beauty, of that eminent sense that beauty assumes in the feminine (1979: 262-263).

This quite clearly manifests that in order to be the Other, to have a meaningful face, a woman needs to go beyond the erotic relation, ergo not be the woman since, according to Lévinas, femininity is defined through eroticism. Correspondingly, in order to be the subject she should not identify herself with femininity. Thus, we see that both the role of the Same and the Other are definitely masculine roles. We are dealing not only with the virile power of the subject but also with the masculine helplessness of the Other.

In the reflections on the nuances of Lévinas's understanding of otherness it is worth noting a certain correlation between femininity - the otherness having an intermediary function, and God - the final otherness. Lévinas does not wish to be a philosopher of religion in a classical sense; however, the Infinity that suddenly emerges through the Face emanating from a certain fragment of the Other's body, is eventually called "God" by him.

In some respects, divinity and femininity operate similarly in the thought of the Same - as an impenetrable mystery that cannot be thematised. It is not difficult to anticipate that within such a constellation divinity will mean true transcendence towards which the Same aims. Nevertheless, the analogy is disturbing. Edmond Jabés, who dealt with the Hebrew experience of divinity as an absence, wrote that: "Upon the creation of animals and plants God was everything apart from the flora and fauna of the globe. Upon the creation of man God was left faceless" (in: Pieszak 2003: 133-134). Hence, the face is what was used by God to allow the man to become the actual man. He himself was left without a face. The man, on the other hand, following God's example, confers his own face upon objects in the process of creation.

Thus, it is apparent that the proper - divine - otherness is found "beyond the face" and this is how one should understand the title of the part of Totality and Infinity - the otherness comes from beyond the face. The face is a human reflection of the source transcendence - a trace of God. However, conversely to divinity, femininity resides "beyond the face". The woman did not void herself of the face in the act of creation, she never had one. She is not so much "beyond the face" as simply "without the face". She is a chthonic otherness, indicating the dark interior of the body. When God created a woman, he was already deprived of his face. He opened the man's body and extracted a rib. Hence, what did God offer a woman? Perhaps the very capability of opening the body and eliciting something new from it? However, as we remember, this capability was deemed sinful by the Biblical author as a punishment for disobedience. 
The likeness of the Same and the "correct form" of the Other consist in the original relationship between God and the man. The man was endowed with God's face. The face itself institutes man's identity but also reminds of the fact that God no longer has a face, it is a trace of the Other, a remainder of the act of original endowment. Hence, the subject's experience of the expression of the face of the other that shows the fear of its identity may put the subject's egoism in question. This implies that despite the separate worlds, identity and otherness somehow overlap and coexist. This perspective affords better understanding of why it is the Other that determines the Same, how the asymmetry of this system works.

This is how femininity again reveals its specificity. By being excluded from the encounter and the conversation, it truly constitutes the most absolute otherness. Femininity plays its role in the maturing of the Same in order to later discretely step aside and not disturb the ethical meeting between the man and the God. The Same does not recognise the original creator in the feminine otherness despite all the metaphysics connected with the act of birth. Thus, my initial hypothesis may see itself reflected in a mirror. The woman is not the correct otherness only because she does not reach the subject's situation but - she never fully becomes the subject as she is not the correct form of otherness.

\section{Without the Hand - hidden at home}

Another carnal phenomenon demarcating the ontological position of femininity is "the hand". Lévinas writes that identity is formed through action. Labour is the effort undertaken by the subject thanks to which is has the power to silence the il $y$ a's whispers and contain the elements. Working means leaving behind the era of childhood and taking responsibility for oneself. Conquering the resistance of the matter through work grants the Same the notion of happiness and freedom. The experience derived from activity establishes its identity. It separates the subject and prepares it for the meeting with the Other ${ }^{28}$.

In Lévinas's depiction the hand is a phenomenon reflecting the process of the subject's creation, his labour. The hand's movement is a gesture manifesting the power that the subject wields over the world. The hand grasps objects and seizes them, collects them at "home". It picks up a tool, works, enjoys, fights, as well as opens and closes the door, as, among other things, the subject's power entails the possibility of freely leaving and returning home. This is what being the Same truly means.

\footnotetext{
${ }^{28}$ Expressions like "meeting with the Other" do not have empirical but phenomenological meaning in Lévinas's texts. I use this phrase following Michael B. Smith, Alphonso Lingis and Barbara Harshav (Lévinas 1994: 162; 1987a: 58; 1998: 8, 202).
} 
"The home" is an incredibly important category here. By possession of a home the subject may collect goods and rest after completing his struggle with the elements. The home opens the possibility to work, to be a subject. This is also where a woman appears, inhabiting the tranquil space amidst the elements. She dwells in it, always and forever, as she is the primordial otherness - the first that the subject will meet upon the awakening. Femininity is "built into" the homestead in which the subject matures, rests, separates himself, the departure point from which he sets out on his adventure with the purpose to establish his identity. So, if we attempt to play with the dimensions of the interior and the exterior, search for the limits, femininity will reveal itself as an otherness emerging from the inside of identity despite the fact that with regard to the Same it manifests the absolute otherness. This is yet another paradox, one of many, which are inscribed into the phenomenology of a woman.

The intimacy of a home allows the male subject's identity to sprout thanks to the presence of the idea of Infinity, which is here expressed with "the feminine grace of its radiance". Femininity is existentially related to the home, which, according to Lévinas, takes a particular place in the hierarchy of human objectives. Yet, as he emphasises - it is not the place of final destination. Thus, if in concord with Lévinas's writings, the final aim is constituted by the epiphany and meeting the Other in a metaphysical relation, it is necessary to keep in mind that the home is not a proper place for the revelation of the Face. Otherwise, how would the Same be able to focus or curl up upon his return home if what awaited him was the permanent epiphany? And once more, Lévinas may support his views with the principle of equivocation. As much as the Beloved was presented as a figure enabling such a communion with the Other that allowed enjoying in him despite the shame, the femininity that we encounter at home, is there and at the same time it discretely is-not. "The Other whose presence is discreetly an absence, with which is accomplished the primary hospitable welcome which describes the field of intimacy, is the Woman" (1979: 155).

Thanks to femininity, as Lévinas states, the home is not a certain gap in the existence, nothingness where the weary Same sits down for a moment. A woman "arranges" the home, makes it warm and cosy so that the focus will be connected with the sweetness of intimacy. The home is also "set back from the anonymity of the earth, the air, the light, the forest, the road, the sea, the river" (1979: 156), as it enables separation from natural existence in an element. In the end, such a direct enjoyment of the element gives rise to uncertainty and care, whereas the home allows setting the struggle aside, gaining strength. Hence, similarly to Nietzsche's theory, femininity is associated by Lévinas with a "warrior's rest". It is "the condition for recollection, the interiority of the Home, and inhabitation" (1979: 155). 
Nevertheless the home, though we may indulge in it, does not allow for the possibility of enjoyment. The lack of possibility to enjoy oneself means bringing the process of the subject's development to a halt. Thus, at home the Same takes a rest from working on himself. He digests the content brought in from the world. He relaxes "at his own place" and gathers strength before continuing his struggle with the elements. This "own place" - the home - assures preservation of the necessary distance to the world. The home, as it may be derived from above reflections, is not a place of work. In order to be it, it would have to constitute a certain type of an element. However, with the appropriating movement of the hand, a cave or a building becomes torn out from the elements and begins to constitute something own - the home. The home is depicted as a place of rest, not work.

Isn't this a confirmation of the stereotype concerned with not recognising the woman's labour in the house as appreciable, as a labour tout court? Although Lévinas wishes to attribute femininity with positive values, in defiance of tradition, still it is the traditional depiction of femininity in which he sees its origins. Hence, the essence of femininity is found in the sweet awaiting of the Same at home, with the woman's being discreetly busy while he rests, the absent presence to allow him being alone, yet not lonely. Indeed, this has barely anything in common with real women who often emanate with frustration and exhaustion instead of sweetness, who demand appreciation, are filled with hatred to husbands that come and leave as they please. Why shouldn't we construe phenomenology of such femininity?

What is also curious, is that the phenomenology of femininity constituting the Dwelling is so distinct from the phenomenology of the Beloved. It seems as if we were faced with two disparate types of femininity, whilst Lévinas in fact speaks of one - the original femininity. When portraying the domesticated woman he contemplates that: "Those silent comings and goings of the feminine being are not the turbid mystery of the animal and feline presence whose strange ambiguity Baudelaire likes to evoke" (1979: 156). Nonetheless, in the chapter Phenomenology of Eros, he himself invokes characterisations that would be more suitable for Baudelaire, where equivocation proves to be the basic key to access the truth of the woman's ambivalent nature.

By being originally bound with the home, femininity does not participate either in the labour or enjoyment, ergo it is excluded from the process of subjectivity. Correspondingly as it is in the case of the Beloved, her otherness consists in being held in its starting point rather than in its emergence from the radical exterior. However, this is also the anchorage point in the attempt to find a link between these two figures, to trace certain consistency. This point, or rather an area or a zone, is defined through the body. Lévinas's illustration of the Dwelling refers us towards the phenomenology of the body. 
The body is the place of concentration of consciousness as well as the place where consciousness finds rest. It is not a prison but a home to the soul. Contrary to the idealistic phenomenology presented by Husserl and the Sartrean existentialism, the establishment of the subject does not constitute presenting oneself to himself as being suspended in an empty spiritual space. Before an identity begins to function "for itself" it is already concentrated "in itself", in one's own body. Whereas the Dwelling is the condition for representation "even if representation is a privileged condition, absorbing its condition" (1979: 153). Therefore the subject, which - by wishing to be idealistic - contemplates the world, disremembers the basic assumption of its own structure - the primordial concentration in the intimacy of his home. Lévinas does not want to say that the home and the body are simply the same but that it is the habitation (l'habitation) that causes a building to become a home and a body one's own body.

A body which is not yet recognised as own is merely a fragment of an element and does not allow the interior to perform the gesture of separation, the distancing and awakening of consciousness. It does not enable the enjoyment and labour. In this sense the home and one's own body are the same, as they are the effect of the original habitation. The body-home enables the subject's potential to become fulfilled. It permits supplying the bare hypostasis with the aspects of identity.

However, it should be highlighted that this concentration is what constitutes the home and not vice versa. "Only from this recollection does the building take on the signification of being a dwelling" (1979: 154). Equivalently, thanks to such a recollection the body becomes an own body, the domicile of identity. Hence, the doubt re-emerges. Not every building is a home, therefore doesn't it imply that not every human body is a carrier of identity? What with the hypostasis that is unable to concentrate, to enjoy, to think and work freely? What are the functions of a "consciousness" that has no possibility to separate itself? The word "consciousness" is put into quotation marks as it is basically impossible to speak of consciousness without the said recollection and separation.

Through the analogy between the home and the body and by referring to a woman as "hidden at home", we may also see her as "hidden in a body" and thus find a common ground between the feminine as a care-taker of the home and the Beloved. This "hiding in a body" would explain the ultramateriality assigned to the Beloved, her animality and sexuality. The mere motive of concealing herself, dwelling somewhere between the presence and absence can be found in both descriptions. Moreover, just as the home belongs to the subject - with femininity merely residing there - the body also constitutes the possession of the Same. Femininity that is confined in the body does not have the power to control it. Perhaps the transformation of primordial domes- 
ticated femininity into its unpredictable erotic form is a gesture manifesting the need to escape from the home, from the authority of a masculine subject. However, this is where disappointment awaits, since the body itself proves to be subjected to this very power. To the extent that at some point - as we will later see - it becomes the home for another the Same, the son.

Woman's hiding at home also makes her incapable of participating in the public life. She is not destined for the "serious matters" that men deal with. She remains in a private, intimate sphere, irrespective of the fact that she is the Beloved or the guardian of the home. "The feminine is the other refractory to society, member of a dual society, an intimate society, a society without language" (1979: 265). Whereas the idea of infinity is expressed in the opposition to a discourse (le discours) occurring in a social context, and habitation is not yet the transcendence of the language - as Lévinas would say. The language utilised by transcendent existence is a social one - it relates to justice. The woman is the other that is excluded from such a discourse.

\section{With a belly - carrying the Other, the little Same}

In the encounter with the female Other, the Same oscillates between the fear of the secrecy of otherness and the temptation of profanation found in the caress and enjoying the revealed sacredness. However, "the profanation that violates a secret does not «discover», beyond the face, another more profound I which this face would express; it discovers the child" (1979: 267). Hence, the real salvation is found in the fact that the sexual act does not merely consist in enjoying the Other, the ecstasy and playing with one's own identity, but also and for Lévinas most of all - it is an act of creation. A child is a fruit of love of two people, the Other par excellence. It is weak, entirely dependent and emerges from the amorphous il $y a$; it is the embodiment of unpredictable future. Thus, this meeting is of an intermediary nature as well. It is not a purpose and a value in itself but it constitutes a mean to a much greater goal - meeting with the child's otherness. Fecundity (la fécondite) sanctions taking enjoyment in femininity. Therefore, a woman-mother is by no means an active figure in the drama of birth. Furthermore, it turns out that the said "child" is in fact a son.

Possession of the child by the father does not exhaust the meaning of the relationship that is accomplished in paternity, where the father discovers himself only in the gestures of his son, but in his substance and his unicity. My child is a stranger (Isaiah 49), but a stranger who is not only mine, for he is me (Lévinas 1979: 267).

What we observe is a certain type of phenomenology of genetics. In his son the Same encounters both: the Other with whom he may enter into a relationship, and himself, self-affirmed and ready to further affirm the life. 
This is how the I revives its substance, simultaneously avoiding the subject's constant return into himself as older and more overwhelmed with itself. "In fecundity the tedium of this repetition ceases; the I is other and young, yet the ipseity (ipséité)" (1979: 268).

Transcendence is realised through transsubstantiation, a certain transfer of the substance of desire from one body into another. Fecundity overcomes death as a resurrection. What resurrects is the new desire of the Infinity. It is not the human that is immortal but this very desire. The desire that fulfils itself through fecundity, by conceiving a new desire. The Same fulfils himself in his existence by producing another fertile being. A father produces a son. Thus, if a father-man-the Same wishes for his own continuity he must expect a son. A daughter would be a female Other and as such would not desire the Infinity, as this kind of desire is what defines the male Same. With regard to the subject, the male element is the necessary pre-condition.

In a book subsequent to Totality and Infinity Lévinas considerably modified the specifics of circumstances of the meeting. The new language of Otherwise than Being, or Beyond Essence, among other things, consists in the fact that we no longer encounter the Same as often, and instead of him the same appears, the One (l'Un) or simply the subject. Also the Other is written with a lowercase letter and is more frequently linked to another person then to God. The metaphysical relationship is rendered with the use of the following concepts: the Same - the Other was to emboss the separation, highlight the identification of I and the subject's otherness, whereas the terminology: I - Another emphasises the personal character of the meeting. Above all, however, what I find the most interesting is that the subject's description contains the category of motherhood.

The cause of this alteration seems intriguing as it may be found in the polemics between Lévinas and Derrida concerned with the category of a woman.

Totality and Infinity

pushes the respect for dissymmetry so far that it seems to us impossible, essentially impossible, that it could have been written by a woman. Its philosophical subject is man (vir) (Cf., for example, the Phenomenology of Eros, which occupies such an important place in the book's economy). Is not this principled impossibility for a book to have been written by a woman unique in the history of metaphysical writing? Lévinas acknowledges elsewhere that femininity is an "ontological category". Should this remark be placed in relation to the essential virility of metaphysical language? But perhaps metaphysical desire is essentially virile, even in what is called woman (Derrida 2005: 412).

Lévinas comments on this allegation by stating that the problem lies not in the content of Totality and Infinity but in the way it has been expressed. By making a reference to Derrida's critical essay on the perspective presented in Totality entitled Violence et métaphisique Essai sur la pensée d'Emmanuel Lévi- 
nas: An Essay on the Thought of Emmanuel Lévinas, Lévinas states that "the critical statement made by Derrida must have been facilitated by the language used in Totalité et Infini, that was carelessly ontological (mainly in fear of not being perceived as psychological)" (in: Logos i Ethos 1991: 114) ${ }^{29}$.

However, Derrida's reproach was not limited only to the language. It also is difficult to consider the transformation of Lévinas's thought in Otherwise than Being to be purely linguistic. In this short fragment, Derrida - firstly - explicitly claims that Lévinas's concept of asymmetry utilised in the chapter entitled Phenomenology of Eros indicates a strictly male perspective of the subject philosophising in Totality, i.e. of Lévinas himself. Secondly, he notes that with regard to the thus far practised philosophy this is unprecedented and questions not only the sexual neutrality of metaphysics as it was known but also the metaphysical desire as such.

In his new theory, Lévinas describes subjectivity with the use of properties that he sees as feminine, or, to be more precise - motherly. By final abandonment of ontology and his fear of being accused of psychologism - the most severe one for a phenomenologist - Lévinas to a certain degree also abandons the Same, or at least abandons what was the unquestioned legacy of a classical subject. As much as the criticism of the subject of Totality allowed this subject to be preserved, now, in order to be retained, the subject itself changes radically. Firstly, we are no longer dealing with an active subject. This heroic conqueror of the world, by opening himself to the Other becomes sensitive, feeling and susceptible to becoming hurt. It turns out that what he thus far considered to be his subjectivity was merely a mask, a shell concealing his soft interior. The consciousness, knowledge, intentionality, everything that is captured into a system, the said - becomes transgressed in the act of resignation and passive sacrifice to the other or even for the other.

The said (le dit) as an act of statement aimed to identify and name ends the initial passivity of the language (le dire). Thus, it may seem that le dit always wins as it is ready to capture the language at its very "beginning". Hence, how is it possible to return to the original passivity? How is it possible to find meaning beyond the said that establishes the sense? In what way may the face have a meaning beyond the essence ${ }^{30}$ ? Doesn't revealing itself mean an in-

\footnotetext{
${ }^{29}$ In correspondence provided to Marek Jędraszewski by Simon Decloux. "La tấche critique de Derrida fut certes, entre autres, facilitée par le langage imprudemment ontologique de Totalité et Infini (et qui le fut surtout par crainte de paraitre psychologique)".

${ }^{30}$ Lévinas utilises the term "essence" in a specific sense: "the term essence here expresses being different from beings, the German Sein distinguished from Seiendes, the Latin esse distinguished from the Scholastic ens. We have not ventured to write essence as would be required by the history of the language, where the suffix -ance, dering from -antia or -entia, gave birth to abstract nouns of action. We shall carefully avoid using the term essence or its derivates in their traditional usage. For essence, essential, essentially, we will say eidos, eidetic, eidetically, or nature, quiddity, fundamental, etc.". (Decloux-Levinas 1991: 7).
} 
stant appearance in the light? Lévinas responds that language "as a pure for another" is in fact possible. The making of a sign itself, "making oneself a sign", pure "expression [ex-pression] of self, sincerity, pure passivity" (Decloux-Levinas 1991: 62). What Lévinas means is the action of making a sign which itself does not suggest any substance yet. Therefore, it is no longer about understanding "what" is being said but opening oneself to the fact "that" it is being said.

Now the subject and the other are explicitly brought closer to each other - as people, weak and awaiting help, giving signs to each other. Transcendence occurs in a relationship between two human beings, yet it comes from beyond them. The discourse that the two subjects use to communicate - when the One calls upon another - preserves the trait of this radical otherness that, in the end, neither of them represents. It is a trace of what has never been present, ergo it has never been the subject. This is when "the Third" (le tiers) begins to participate in the meeting and the discourse between the subject and the other, and this time it does not mean the third man, as it was in Totality because he has no access to the epiphany between those two, but it is rather about Him - the mysterious "illeity" (lilléite) that Lévinas hesitates to call the God ${ }^{31}$. We may note, however, that the new perspective of Otherwise than Being consists, among other things, in the fact that Otherness is even more strongly elicited from the interpersonal space which causes people to grow closer to one another. The Same is no longer as strong and active, whereas the Other - acting as the second subject here - ceases to be so different. This way, the asymmetry gains a slightly altered dimension. It is not as radical as in Totality. An intrigue involving three characters takes place involving "dual asymmetry: between the God and the subject, as well as between fellow human being and the subject" (Jędraszewski 1991: 108).

Nonetheless, this does not explain the problem of social relations in which femininity in fact does not participate. Lévinas aims to resolve this issue by transferring epiphany onto community. The primary concept - besides the responsibility that was concerned with the Same - rests in justice conditioned by the "presence" of transcendence (or should we rather say the absence, as it is beyond essence). According to Lévinas, the goodness that people should lean their actions on does not consist of love or charity but rather justice towards Another. This is where we may notice the impact of Judaism on Lévinas's concept. What is characteristic, both for Judaism and Lévinas, is the assumption that the man is only capable of justice when he commits himself to

\footnotetext{
${ }^{31}$ Despite this caution, the "third" is eventually referred to as the God and the consequences feared by Lévinas become in fact imminent. He himself strongly opposes the idea that his thought is theological. He claims that philosophy should be separated from the Bible and that he himself is a different author when he deals with the exegesis of the Bible or when he writes philosophical books. He convinces that the real source of his philosophy originates in phenomenology (in: Lévinas - an interview 1995: 130).
} 
the laws of God. The laws recorded on the pages of the Old Testament. One may ask why it is the Israeli nation that is considered chosen? A nation - i.e. a social structure. "If being chosen takes on a national appearance, it is because only in this form can a civilisation be constituted, be maintained, be transmitted, and endure" (Lévinas 1990: 138).

What form is that? - we keep asking. Lévinas replies: "Abraham was not the first to recognise God, but he was the first to found a monotheist family" (1990: 138). Monotheistic - would not necessarily imply - patriarchal - yet it means that since the Israel's God is definitely male in nature, he is the Father. Therefore the transfer of this law and pattern onto a social structure bears fruit in the form of establishment of a patriarchal family. Of course, historically speaking, the said process could have taken the reversed course.

Thus, as much as Otherwise than Being wishes to discuss ethics in social life, the emphasis on the "metaphysics" of a family resounds even stronger. Perhaps this is also why the category of motherhood is introduced. Even when we disregard Derrida's critique explicating the ontologism of the figure of femininity, still the transposition of considerations onto a more real, interpersonal ground and their continuous depiction in Judaic perspective will eventually lead Lévinas to the character of a mother. However, this is not, as one might expect, a rehabilitation of a figure of a woman, the final admittance of her right to subjectivity.

The concept of the subject modified in Otherwise than Being is not as much of a disproof of the previous one as it is its complementation. The masculine Same was not limited to the cognitive cogito nor the pure Husserlian I. Its most fundamental characterisation was related to an enjoyment and sensual experience of the elements, consuming food that he snatched from the world and that was prepared at home by a woman. Enjoyment will still play an important role in the subject's constitution. However, in Otherwise than Being the subject abandons his virile power for the benefit of sensitivity and closeness with another person. This is mainly a sensual subject.

A sensual impression which philosophy is able to describe is already processed by it, reduced to a phenomenon - to what appears (apparaitre). A subject that examines its impressions - keeps an eye on them - is a subject intentionally targeted on the object of its cognition, or at least - the feeling. The subjectivity that Lévinas wishes to express is not an intentional structure. It is navigated by a Desire that reaches beyond the mere awareness of something. The concept that Lévinas will use in his attempt to describe subjectivity that exceeds and, at the same time, contains intentionality is the psychism (le psychisme). "Thematising consciousness in the privileged role of manifestation that belongs to it, takes on its meaning in the psyche which it does not exhaust, and which has to be described positively" - he writes. This positive de- 
scription will be based on the concept of sensibility that "is in this way situated back in the human exception" (Decloux-Levinas 1991: 67).

Already in Totality we dealt with the description of separation as "internal life, or the psyche"; however, the term "internal life" was used to refer to economy, inhabitancy and returning to one's home, which secured the distance between the subject and transcendence. Now, on the other hand, Lévinas will speak of the closeness to a fellow human being, thus the psychism will not be based on dwelling. It will be defined as a reflection (le reflet) of diachrony ${ }^{32}$.

(...) which is the-one-for-the-other in proximity. It is then not a particular signification. The-one-for-another has the form of sensibility or vulnerability, pure passivity or susceptibility, passive to the point of becoming an inspiration, that is, alterity in the same, the trope of the body animated by the soul, psyche in the form of a hand that gives even the bread taken from its own mouth. Here the psyche is the maternal body (Lévinas 1991: 67).

The expression "the psyche is the maternal body" is equally intriguing and it is unobvious as "the virile power of the subject" (Lévinas 1987b: 54). Lévinas does not say "mother" tout court, but "the maternal body" (le corps maternel). The maternal body is a body that gives birth and feeds. It experiences the pain connected with giving birth to a child, the pain connected with feeding. The mother's body is doomed to this experience as it must accept the germ of life developing inside it - accept the Other. The mother's body passively awaits its fate, commits itself to this situation, gives itself in service of the Other that calls upon it. A baby is naked and hungry, the mother's body provides it with shelter and nourishment. By pointing to the maternal body Lévinas emphasises the absolute passivity or even inertness of motherhood. In this depiction the mother is completely subjected to carnality that serves humanity. She is identified with her body. In Lévinas's thought the mother's body, in fact, means - the mother. Thus, such a concept of motherhood is not related to the authentic feminine maternity with the mother being perceived as a person, or a free subject capable of opposing this situation by at least interpreting it differently. Here, the motherhood, the mother, the mother's body become an allegory used to express absolute passivity. What constitutes the passive, susceptible to being hurt and sensitive subjectivity is the mother's body. The body, which gives birth to those it carried with "the groaning of the wounded entrails". It bears the Others and raises them to be the Sames.

Yet, at the same time, it is necessary to remember that carnality - similarly to passivity - is evaluated positively by Lévinas. It plays an extremely significant role in the mystery of meeting, since in fact the body sacrifices itself, gives itself to the other. This is what the substitution is based on - another category

\footnotetext{
${ }^{32}$ The concept of diachrony is used to "express the impossibility of reducing the time characteristic of Him to the presence of awareness" (Jędraszewski 1991: 107).
} 
describing the meeting with the Other. "Such a signification [of substitution MA] is only possible as an incarnation" - Lévinas writes (Decloux-Levinas 1991: 69). The one-for-the other structure is what defines the carnality of the same. Opening oneself to the other is the opening of carnality. The intentionality that we tend to perceive as a manifestation of the psyche is secondary with regard to carnality. The psyche par excellence is a living body, which means - a body offered to another person, surrendering itself to that person.

Animation is not better expressed by the metaphor of inhabitation, the presence of a pilot in the helm of his boat, a vital principle immediately assimilated with a directive principle, or the virility of a logos and a command. Animation can be understood as an exposure to the other in vulnerability, which refers to maternity, which sensibility signifies (Decloux-Levinas 1991: 71).

Lévinas comes across motherhood whilst seeking for the original sensitivity, the incipient opening to Another, which precedes the aware subjectivity thematising and seizing the world, that is the virile subjectivity. This is a journey to the very source of human psyche which Lévinas discovers in the maternal aspect of femininity ${ }^{33}$, similarly as it is done by analytical psychology. As a quintessence of sensitivity in its pre-natural meaning, motherhood becomes a remedy to the power of logos. This meaning precedes any intentionality that thus far was "a guiding thread towards the eidos of the psyche".

Once more we find confusion in the relationship between "the phenomenon of maternity" and maternity as an attribute of femininity, an empirical experience. It is not explicit whether maternity is a supra-sexual category that is vested to subjects irrespective of their sex. It is certain that this is Lévinas's intention; however, it does not change the fact that in cultural, social and biological terms maternity refers only to mothers - the women that have become mothers. Still, even if we treat maternity as an aspect that founds the psyche of each person, and moreover we find awareness in it, the feeling of freedom and virile power, we will find ourselves in the hiatus between consciousness and unconsciousness seen as predetermined by sex. Irrespective of whether we inverse the classical option and let unconsciousness play the first fiddle, we will still keep repeating the old dichotomy, where sensitivity and unawareness define the world of women, and the logos and power - that of men. The moment this interpretation inevitably, permeates the world of the actual living men and women, we are faced with women being refused the right to rational thinking and acting freely, just as we will see men that are not allowed to cry.

The lack of a relationship between maternity and femininity is surprising. As much as such a relationship would seem obvious, the text of Otherwise than

\footnotetext{
${ }^{33}$ Here, femininity would be identified with the primordial invariability and unawareness as an ocean revealing islands of consciousness.
} 
Being does not make a single reference to "femininity" with regard to motherhood. What does it mean? That a woman is still cast beyond subjectivity. The subject that defies the masculine subject is the maternal subject and not feminine! This distinction is incredibly important. Femininity stands for eroticism, virginity and impudence all at the same time. Moreover, femininity means dwelling and taking care of the enjoying Same. These are figures of otherness. Maternity, on the other hand, reflects the original subjectivity, the one that is the most constitutional for mankind. Therefore, the lack of reference of motherhood to the previously invoked figure of femininity would highlight the separation of maternity from sex. This way maternity is made available to the masculine Same, it transforms it, changes its subjectivity. Is not this a part of the message stating that prophet Elias is simultaneously the mother and the father of the Israeli nation and that none of the feminine figures is capable of fulfilling this role?

True life, joy, pardon and peace no longer belong to woman. Now there rises up, foreign to all compassion for itself, spirit in its essence, virile, superhuman, solitary. It recognises itself in Elijah, the prophet without pardon, the prophet of anger and punishment, a suckling of crows, inhabiting deserts, without kindness, without happiness, without peace. (...) the figure in whom is stored up for the Jews all the tenderness of the earth, the hand which caresses and rocks his children, is no longer feminine. Neither wife nor sister nor mother guides it. It is Elijah, who did not experience death, the most severe of the prophets, precursor of the Messiah (Lévinas 1990: 38).

Elias reaches to the women's functionality involving giving birth, thus depriving them of the most significant difference in which they could find their identity. Femininity cannot evolve into maternity also for a simple reason that the phase of the enjoying Same is indispensable to reveal sensibility. Egoism is necessary in order to make suffering meaningful. "Winding of a skein, it is the very movement of egoism. It has to be able to be complacent in itself, as though it exhausted the eidos of sensibility, so that sensibility could, in its passivity, its patience and pain, signify for the other by unwinding its coils" (Lévinas 1991: 73).

Yet, on the other hand, if regardless of all we insist to see the category of motherhood as feminine, we will be faced with a limitation of feminine subjective possibilities only to maternity. A woman would finally become a subject - as a mother. Only motherhood would position her in the subject area, in the society. This is the subjectivity that has never possessed itself, that have always served the other. It remains within an ambiguous area, always in the substitution, never in a joy of living. In its permanent passivity, "having been offered without any holding back", and there is no initiative to offer gifts. A mother gives birth to a child, she takes care of it, yet it is not her free choice. Besides, what is very important to mention, in Judaism, to which I referred while analysing Lévinas's work entitled Judaism and Femininity, maternity is 
not a personal strength of a woman, it does not build her identity, it is interwoven in the context of "saving of humanity" and used to serve the fate of mankind.

\section{Conclusion: The Ethics and the female Infinite}

Thus, the specificity of femininity envisaged in Lévinas's concept rests in the fact that it constitutes an intermediary figure. "The not-yet-being" that aims towards being remains in the grey zone between the sub-jectivity and otherness. The woman here is closed in her carnality, being the body of Beloved or Mother. As an erotic body, she blocks the possibility of transcendence of the Same, as a maternal body she is consumed by her destiny of carrying and feeding the son. In both roles she is neither the subject nor the Other in the correct form. She is something in between.

In my view, this questions the entire ethical project created by Lévinas. His primary intention was to create such metaphysics that would constitute ethics and not ontology and could restore faith in human values in the Western world after the Second World War. One that would not be based on norms and commands but rather on an encounter between human beings. Face to face. Hence, the category of the Other as the Infinite, the one that opens its ego to transcendence is what prevails in Lévinas's project.

Femininity, on the other hand, as a figure of otherness is omitted in the new ethics, as it is not the correct otherness. It is a static intermediate between the broad multifaceted concept of the subject and the vision of the Other than goes beyond ontology. It is an intermediary figure between the old and the new metaphysics, between the Totality and the Infinity, the Father and the Son. As Nietzsche fantasised: "not to be dead and yet no longer alive a spirit like intermediate being, quietly observing, gliding, floating" (Derrida 1998: 52).

This way the reflections on Lévinas's text confirm how important it is for philosophy to come to the critical understanding of the sex difference. What is meant is not the critique of the feminist thought where a lot is being discussed in this respect. I mean the "classical" philosophical trends aspiring to being seen as objective and producing universal categories. The sexual difference is not only the "problem of feminists". It is a challenge ahead of the humanities as such. The Otherness of a woman expressed by a man-philosopher should not be of absolute nature nor should it be recognised as the essence of femininity. It should not rule out its functioning as a subject. And finally, the woman should not be permanently other for herself, which would be the inevitable consequence of it being identified with otherness. Instead, let her be less mysterious and more familiar, ordinary, illuminated and free. 


\section{Literature}

Adamiak, M. 2007. O kobiecie, która nawiedza myśl. Kobieta jako figura inności w koncepcji podmiotu Emmanuela Lévinasa. Warszawa: Wydawnictwa Akademickie i Profesjonalne.

Angier, N. 2000. Woman: An Intimate Geography. New York: Knopf Doubleday Publishing Group.

Decloux-Levinas. 1991. Korespondencja między Emmanuelem Lévinasem i Simonem Decloux. Transl. M. Jędraszewski. Logos i Ethos, 1 (1): 111-120.

Derrida, J. 1998. The Question of Style. Transl. R. Berezdivin. K. Oliver \& M. Pearsall, ed. Feminist Interpretations of Friedrich Nietzsche: 50-65. University Park, Pennsylvania: The Pennsylvania State University Press.

Derrida, J. 2005. Violence and Metaphysics: An Essay on the Thought of Emmanuel Lévinas. Transl. A. Bass. Writing and Difference: 97-192. London \& New York: Routlege.

Jędraszewski, M. 1991. Między “Totalité et Infini" a "Autrement qu’etre ou audélá de l'essence". Korespondencja Emmanuela Lévinasa z Simonem Decloux. Logos i Ethos, 1 (1): 99-110.

Lévinas, E. 1979. Totality and Infinity. An Essay on Exteriority. Transl. A. Lingis, The Hague/Boston/London: Martinus Nijhoff Publishers \& Duquesne University Press.

Lévinas, E. 1987a. Philosophy and the Idea of Infinity. Transl. A. Lingis. Emmanuel Lévinas: Collected Philosophical Papers. Boston: Martinus Nijhoff Publishers.

Lévinas, E. 1987b. Time and the Other \& Additional Essays. Transl. R. A. Cohen, Pittsburgh: Duquesne University Press.

Lévinas, E. 1990. Difficult Freedom, Essays on Judaism. Transl. S. Hand. Baltimore: The Johns Hopkins University Press.

Lévinas, E. 1991. Otherwise than Being, or Beyond Essence. Transl. A. Lingis, Dordrecht: Kluwer Academic Publishers.

Lévinas, E. 1994. In the Time of the Nations. Transl. Michael B. Smith, Bloomington \& Indianapolis: Indiana University Press.

Lévinas, E., Münster, A., et al. 1995. La Différence comme non-indifférence: Éthique et altérité chez Emmanuel Lévinas: le séminaire du Collège international de philosophie. Paris: Editions Kimé.

Lévinas, E. 1998. Entre Nous, On-Thinking-of-the-Other. Transl. M. B. Smith, B. Harshav. New York: Columbia University Press. 
Pieszak, E. 2003. Trzy dyskursy o spotkaniu z Innym. Gombrowicza, Schelera i Lévinasa ścieżki spotkania $w$ pobliżu wielkich dróg. Poznań: Wydawnictwo Poznańskiego Towarzystwa Przyjaciół Nauk. 